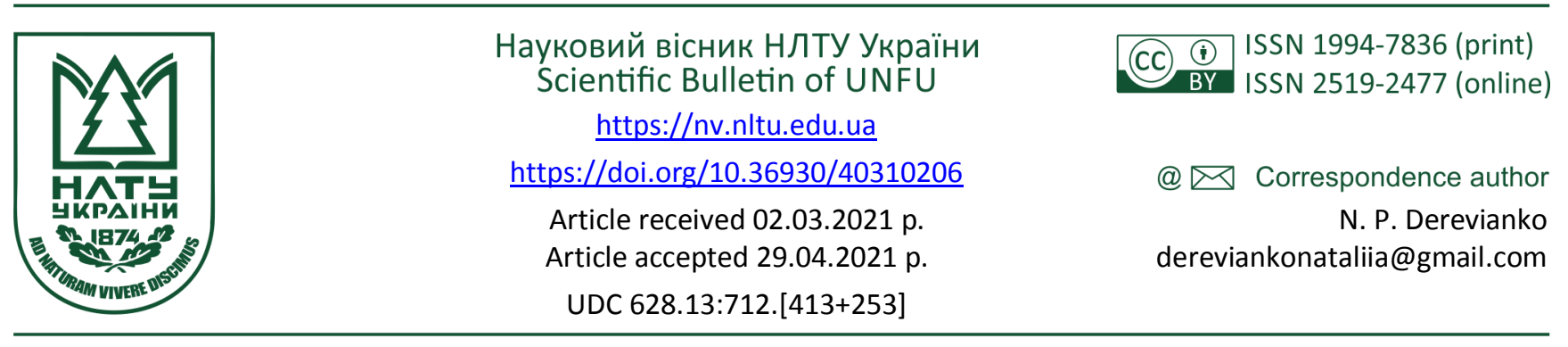

Н. П. Дерев'янко

Хортицька національна навчально-реабілітаційна академія, м. Запоріжжя, Україна

\title{
ПРОЄКТ БЛАГОУСТРОЮ ТА ОЗЕЛЕНЕННЯ ВНУТРІШНЬО-КВАРТАЛЬНОЇ ТЕРИТОРІї У МІСТІ ЗАПОРІЖЖЯ
}

Важливим заходом, що дає змогу надати старій прибудинковій території привабливого естетичного та екологічного стану, є іiї озеленення. Зокрема, новий благоустрій двору багатоквартирного будинку є важливим 3 погляду зручності розташування необхідних об'єктів інфраструктури, які не враховувались під час будівництва будинку. Для цього може знадобитися робота над рельєфом і ландшафтом та зведення малих архітектурних споруд. Територія розташована за адресою вул. Гудименко, 22 (вул. Героїв 93-ї бригади), міста Запоріжжя та потребує певних змін як з погляду будівельних робіт, так і з ландшафтного дизайну. Ділянка розташована у Хортицькому районі у формі прямокутника. Площа об'єкта - $13125 \mathrm{~m}^{2}$. 3 усіх боків оточена житловими дев'ятиповерховими будинками та обмежена проїзною дорогою. Упродовж дня ділянка добре освітлюється, але світла від ліхтарів недостатньо у темну пору доби. Ця територія досить людна як рано, так і ввечері, тому що поряд розміщені школа та дитячий садок. Розроблений проєкт благоустрою та озеленення внутрішньо-квартальної території значно покращить вигляд цього об'єкта. За допомогою інвентаризації встановлено такі показники, як: баланс території, видовий та породний склад дерев і чагарників, їх кількість, стан і особливості, стан газону. Відповідно зміна зовнішнього вигляду об'єкта озеленення зробить його набагато зручнішим у користуванні. Заплановано висадити декілька композицій, в асортимент яких будуть входити хвойні дерева та чагарники, вічнозелені, листопадні кущі, багаторічні та грунтопокривні рослини. Запроєктовано невеликий живопліт з вічнозелених багаторічних кущів, посаджених у формі незавершеного прямокутника, на території, яка оточує торгівельний МАФ.

Ключові слова: озеленення території; міські будівлі; доріжки; лавки; дитячий майданчик.

\section{Вступ}

У великих і малих містах велике значення має створення озеленених міських зон, тому що зелені насадження покращують мікроклімат території, утворюють комфортний відпочинок на відкритому повітрі, захищають грунт, стіни будинків і тротуарів від перегрівання в літній період та захищають від вітрів у всі пори року [3].

Основна частина внутрішньо-квартальних та прибудинкових територій, створених у 1960-1990 рр., перебувають у незадовільному стані та потребують повної або часткової реконструкції способом озеленення [13].

Дуже важливо у наш час стрімкого темпу життя створювати комфортні умови, які дадуть змогу відпочити від міського середовища і роботи, а зручні просторово-композиційні рішення будуть позитивно впливати на фізичний та психологічний стан людей [8].

Об'єкт дослідження - благоустрій та озеленення внутрішньо-квартальної прибудинкової території.

Предмет дослідження - методи і засоби обстеження та внесення проєктних пропозицій щодо благоустрою та озеленення внутрішньо-квартальної прибудинкової території у місті Запоріжжя.

Мета роботи - розроблення проєкту благоустрою та озеленення внутрішньо-квартальної прибудинкової території, що дасть змогу покращити її мікроклімат, утворить комфортний відпочинок на відкритому повітрі, захистить грунт і покриття, стіни будинків і тротуарів від перегрівання в літній період та захистить від вітрів у всі пори року.

Для досягнення зазначеної мети визначено такі основні завдання дослідження:

- провести детальне обстеження об'єкта проєктування;

- зробити інвентаризацію наявних насаджень;

- розробити пропозиції щодо планування території, підібрати відповідну рослинність і елементи благоустрою, обладнання;

- скласти графічні креслення.

Наукова новизна отриманих результатів дослідження - вперше розроблено нові пропозиції з благоустрою та озеленення внутрішньо-квартальної території, що значно покращить мікроклімат території, утворить комфортний відпочинок на відкритому повітрі, захистить грунт, стіни будинків і тротуарів від перегрівання в літній період та захищадить від вітрів у всі пори року.

Практична значущість результатів дослідження може бути використана як перспективний проєкт для подальшої реалізації благоустрою та озеленення внутрішньо-квартальної території по вулиці Гудименко, 22

Інформація про авторів:

Дерев'янко Наталія Петрівна, канд. с.-г. наук, доцент, завідувач кафедри садово-паркового господарства.

Email: dereviankonataliia@gmail.com; https://orcid.org/0000-0002-7255-493X

Цитування за ДСТУ: Дерев'янко Н. П. Проєкт благоустрою та озеленення внутрішньо-квартальної території у місті Запоріжжя. Науковий вісник НЛТУ України. 2021, т. 31, № 2. С. 40-45.

Citation APA: Derevianko, N. P. (2021). Project of welfare planning and landscaping of the inter-quarterly territory in the city Zaporizhzya. Scientific Bulletin of UNFU, 31(2), 40-45. https://doi.org/10.36930/40310206 
(вул. Героїв 93-ї бригади) та подібних територій.

Аналіз останніх досліджень та публікацій. Якість середовища проживання безпосередньо впливає на життєдіяльність людей, їх психологічний та емоційний стан, самопочуття і настрій. Високий рівень благоустрою територій забудови населених пунктів повинен забезпечити створення сучасного, безпечного, комфортного та естетично повноцінного середовища.

Містобудування $є$ матеріально-просторовим відображенням суспільних поглядів і очікувань у формуванні повноцінного середовища [9]. Це визначає основи державної містобудівної політики в Україні, яка регулюється Конституцією України, Цивільним, Господарським і Земельним кодексами України, законами і нормативно-правовими актами, в тому числі законом України "Про основи містобудування", "Про планування і забудову території", "Про Генеральну схему планування території України", "Про регулювання містобудівної діяльності", "Про благоустрій населених пунктів" $[19,20,21,22]$. Аналіз стану вивченості аспектів благоустрою та його заходів для організації якісного середовища показав, що дана проблема знайшла відображення в роботах багатьох авторів [1, 2, 4, 5, 7, 9, 12, 16, 17].

Благоустрій населених пунктів визначається в словнику "Архітектурні терміни" як "створення здорових, зручних і культурних умов життя для населення в місті, селищі, селі, на курорті тощо. $Є$ складовою частиною містобудування і містить роботи з інженерного обладнання, а також санітарногігієнічного стану території (інженерна підготовка територій, влаштування доріг, проїздів, тротуарів, розвиток міського транспорту, будівництво мереж і споруд водопостачання, каналізації, енергопостачання, озеленення території, поліпшення мікроклімату - влаштування басейнів, фонтанів, охорона від забруднення повітряного простору, водоймищ, грунту, санітарне очищення стоків, зниження рівня міського шуму тощо)..." [18].

За даними Мардером А. П., до благоустрою належать: проектування, будівництво та експлуатація зелених насаджень (у т. ч. приміських зелених зон і внутрішньоміських насаджень загального користування), зон зовнішнього транспорту, вулиць, доріг, площ, комунально-складських районів та підприємств по обслуговуванню транспортних засобів, інженерного устаткування (водопостачання і каналізація, санітарна очистка, електропостачання, тепло- і газопостачання). У вужчому розумінні - упорядкування, обладнання і озеленення загальноміського (селищного, сільського) простору i внутрішньомікрорайонних (внутрішньо-квартальних) просторів житлових і виробничих комплексів..." [11].

Визначення благоустрою, благоустрою населених місць та благоустрою території дається "Українським тлумачним словником будівельних термінів" [10]: $a$ ) "благоустрій - сукупність робіт і заходів, що здійснюються для приведення території до стану, придатного для будівництва або нормального використання за призначенням, створення здорових, зручних і естетичних умов для проживання людини; б) благоустрій населених місць - сукупність робіт і заходів, спрямованих на забезпечення сприятливих умов життя населення; в) благоустрій території - створення на певній території зручностей (споруди, інфраструктура) для життя, роботи і відпочинку людей (водопровід, каналізація, озеле- нення шляхів, лави на зупинках і в парках, дитячі майданчики, бульвари тощо)".

Найбільш повне розкриття аспектів проблеми, що вивчається, знаходимо в законі "Про благоустрій населених пунктів", визначаючому правові, економічні, екологічні, соціальні та організаційні засади благоустрою населених пунктів і спрямованому на створення умов, сприятливих для життєдіяльності людини [22]. Згідно 3 цим законом, "благоустрій населених пунктів - комплекс робіт з інженерного захисту, розчищення, осушення та озеленення території, а також соціально-економічних, організаційно-правових та екологічних заходів 3 покращення мікроклімату, санітарного очищення, зниження рівня шуму та інше, що здійснюються на території населеного пункту з метою ії раціонального використання, належного утримання та охорони, створення умов щодо захисту і відновлення сприятливого для життєдіяльності людини довкілля. Заходи 3 благоустрою населених пунктів - роботи щодо відновлення, належного утримання та раціонального використання територій, охорони та організації упорядкування об'єктів благоустрою з урахуванням особливостей їх використання".

Матеріали та методи досліджсеня. Проєктні роботи та дослідження проводили у 2018-2019 pp. на внутрішньо-квартальній території, що розміщена за адресою вул. Гудименко, 22 (вул. Героїв 93-ї бригади), яка розташована у Хортицькому районі Запоріжжя. Територія проєктованої ділянки 3 усіх боків оточена житловими будинками (рис. 1).

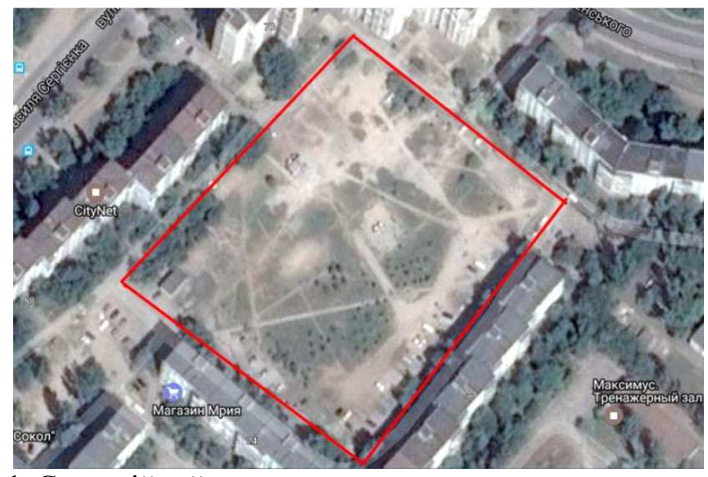

Рис. 1. Ситуаційний план

Здійснено обстеження запропонованої території 3 урахуванням особливостей рельєфу. Визначення механічного складу грунту проводили "мокрим" методом Н. А. Качинського [6, 15]. За допомогою приладу Алямовського визначали реакцію грунтового розчину. Візуально визначали забарвлення грунту та структуру. Інвентаризацію наявних насаджень, інженерних мереж, будівель і споруд здійснено згідно 3 "Інструкцією 3 інвентаризації зелених насаджень у населених пунктах України" [14].

\section{Результати дослідження та їх обговорення}

Під час роботи над проєктом здійснено передпроєктне обстеження грунту та встановлено: механічний склад грунту - суглинок, структуру грунту - пилувато-зерниста, рН водної витяжки - 7,0; колір грунтусвітло-сірий. Грунти з таким забарвленням містять гумусу менш ніж 2 \%. Грунт потребує підживлення.

Одним із основних завдань було проведення інвентаризації наявних насаджень. На підставі отриманих да- 
них складено креслення. Дані обстеження послужили основою для розроблення проєкту щодо покращення стану насаджень та декоративного оформлення об'єкта.

За допомогою інвентаризації було встановлено такі показники: баланс території (загальна площа під зеленими насадженнями, зокрема під деревами, чагарниками, квітниками, газонами, доріжками), які наведено у табл. 1.

Табл. 1. Баланс території

\begin{tabular}{|c|l|c|c|c|c|}
\hline \multirow{2}{*}{$\begin{array}{c}\text { № } \\
3 / п\end{array}$} & Елемент структури & \multicolumn{2}{|c|}{ Сучасний стан } & \multicolumn{2}{|c|}{ За проєктом } \\
\cline { 3 - 6 } & \multicolumn{2}{|c|}{$\mathrm{m}^{2}$} & $\%$ & $\mathrm{~m}^{2}$ & $\%$ \\
\hline 1 & Будинки та споруди & 792,0 & 6,0 & 792,0 & 6,0 \\
\hline 2 & $\begin{array}{l}\text { Покриття доріг, майданчи- } \\
\text { ків, доріжок, зокрема: спе- } \\
\text { ціальне покриття, стоянка } \\
\text { для машин }\end{array}$ & 325,0 & 2,4 & 5476,0 & 41,7 \\
\hline 3 & $\begin{array}{l}\text { Насадження, зокрема: дере- } \\
\text { ва, чагарники, газони }\end{array}$ & 12008,0 & 91,4 & 6857,0 & 52,2 \\
\hline \multicolumn{2}{|l|}{ Разом } & 13125,0 & 100 & 13125,0 & 100 \\
\hline
\end{tabular}

Площа території проєктування зайнята як насадженнями, зокрема деревами, чагарниками, в деяких місцях $\epsilon$ газони, які займають 91,4 \% ділянки, так і такими елементами структури, як: покриття доріг, дитячі та спортивні майданчики, а це 2,4 \% від загальної площі. На ділянці є декілька споруд (трансформаторна будка та торгівельний кіоск), наявна територія для сміттєвих контейнерів.

Проєктом передбачено прокладання нових доріжок та декорування нових і старих доріжок, оброблення поверхні дитячих та спортивного майданчика спеціальним покриттям. Плануємо стоянку для машин, а також ремонт місця під сміттєвими контейнерами. Запроєктовано поставити більше лавочок з урнами.

За проєктом заплановано декілька композицій, які будуть складатись 3 хвойних дерев і чагарників, вічнозелених, листопадних кущів, багаторічних та грунтопокривних рослин. Ці композиції будуть підсвічуватись, що додасть їм ефектного вигляду, а також буде слугуватиме додатковим освітленням у темну пору доби. Територія проєктування виконана у змішаному стилі ландшафтного дизайну, поєднуючи особливості геометричного і пейзажного стилю.

Обстежували також стан і належність стаціонарних інженерно-архітектурних споруджень, підземні і надземні інженерні мережі, санітарну зону інженерних мереж (табл. 2).

Табл. 2. Експлікація надземних і підземних інженерних мереж і комунікацій

\begin{tabular}{|c|c|c|c|}
\hline$№$ 3/п & Тип інженерних мереж & Довжина, м & Розміщення \\
\hline 1 & Електромережа & 660,5 & $\begin{array}{c}\text { Повітряна } \\
\text { Підземна }\end{array}$ \\
\hline 2 & Водопровід & 150,0 & Підземна \\
\hline 3 & Каналізація & 475,0 & Підземна \\
\hline 4 & Газопровід & 130,0 & Підземна \\
\hline
\end{tabular}

Примітка: розміщується на бетонних стовпах $(4,5$ м)

За даними інвентаризації склали необхідні креслення. На садово-парковий об'єкт складено опорний план території у масштабі 1:100. Відомості з аналізу видового та породного складу дерев і чагарників насаджень наведено у табл. 3. Ця ділянка потребує вирубування дерев, які перебувають у незадовільному стані.

Табл. 3. Видовий та породний склад дерев і чагарників

\begin{tabular}{|c|c|c|c|c|c|c|}
\hline \multirow{2}{*}{$\begin{array}{l}\text { № } \\
\text { 3/ח }\end{array}$} & \multicolumn{2}{|c|}{ Порода, вид } & \multirow{2}{*}{$\begin{array}{l}\text { Кількість, } \\
\text { шт. }\end{array}$} & \multirow{2}{*}{$\begin{array}{l}\text { Частка породи в } \\
\text { насадженнях, \% }\end{array}$} & \multirow{2}{*}{ Особливості } & \multirow{2}{*}{ Стан } \\
\hline & Українська назва & Латинь & & & & \\
\hline 1 & Абрикос звичайний & Prunus vulgaris & 30 & 23,0 & $\begin{array}{c}\text { Ефектний під час цві- } \\
\text { тіння }\end{array}$ & $\begin{array}{l}\text { Задовільний, } \\
\text { незадовільний }\end{array}$ \\
\hline 2 & Вишня звичайна & Prunus cerasus & 9 & 6,9 & $\begin{array}{c}\text { Ефектна під час цві- } \\
\text { тіння }\end{array}$ & Задовільний \\
\hline 3 & В'яз граболистий & Ulmus carpinifolia & 2 & 1,5 & $\begin{array}{c}\text { Кора } 3 \text { глибокими трі- } \\
\text { щинами }\end{array}$ & Незадовільний \\
\hline 4 & Горіх волоський & Juglans regia & 13 & 10,0 & $\begin{array}{c}\text { Довговічне } \\
\text { декоративне } \\
\end{array}$ & Задовільний \\
\hline 5 & Горобина звичайна & Sorbus aucuparia & 7 & 5,3 & $\begin{array}{c}\text { Ажурна крона, ефектні } \\
\text { плоди }\end{array}$ & Задовільний \\
\hline 6 & Груша звичайна & Pyrus communis & 2 & 1,5 & Блискуче листя & Задовільний \\
\hline 7 & Клен звичайний & Aser platanoioles & 2 & 1,5 & Ажурна крона & Задовільний \\
\hline 8 & Липа серцелиста & Tilia cordata & 7 & 5,3 & $\begin{array}{c}\text { Цвітіння рясне, квітки } \\
\text { пахучі }\end{array}$ & Задовільний \\
\hline 9 & Робінія псевдоакація & Robinia pseudoacacia & 7 & 5,3 & $\begin{array}{l}\text { Ажурна крона, } \\
\text { рясне цвітіння }\end{array}$ & Задовільний \\
\hline 10 & Слива домашня & Prunus domestica & 9 & 6,9 & $\begin{array}{c}\text { Ефектна під час цві- } \\
\text { тіння } \\
\end{array}$ & Задовільний \\
\hline 11 & Шовковиця чорна & Morus nigra & 5 & 3,8 & $\begin{array}{c}\text { Ажурна густа } \\
\text { крона }\end{array}$ & Незадовільний \\
\hline 12 & Ясен звичайний & Flaxinus excelsior & 24 & 18,4 & Ажурна крона & $\begin{array}{c}\text { Задовільний не- } \\
\text { задовільний }\end{array}$ \\
\hline 13 & Бузок звичайний & Syringa vulgaris & 1 & 0,7 & $\begin{array}{c}\text { Ефектний під час цві- } \\
\text { тіння }\end{array}$ & Незадовільний \\
\hline 14 & Глід звичайний & Crataegus iavigata & 1 & 0,7 & Ефектні плоди & Задовільний \\
\hline 15 & Обліпиха крушиноподібна & $\begin{array}{c}\text { Hippophae rhamno- } \\
\text { ides }\end{array}$ & 1 & 0,7 & Ефектні плоди & Задовільний \\
\hline 16 & Садовий жасмин & \begin{tabular}{|c|}
$\begin{array}{c}\text { Philadelphus grandif- } \\
\text { lorus }\end{array}$ \\
\end{tabular} & 1 & 0,7 & Цвітіння рясне & Незадовільний \\
\hline 17 & Таволга середня & Spiraea media & 1 & 0,7 & $\begin{array}{c}\text { Ефектна під час цві- } \\
\text { тіння }\end{array}$ & Задовільний \\
\hline 18 & Шипшина колюча & Rosa spinosissima & 3 & 2,3 & $\begin{array}{c}\text { Цвітіння рясне, квітки } \\
\text { пахучі }\end{array}$ & Задовільний \\
\hline
\end{tabular}


За результатами аналізу видового та породного складу дерев і чагарників насаджень з'ясовано, що 95 \% насаджень $є$ листопадними рослинами. Їх було висаджено давно, тому вони потребують формувального та санітарного обрізування, але $\epsilon 54 \%$ нових посадок з молодих дерев. Газони (трав'яний покрив) враховані за асортиментом рослин з оцінкою наявного стану (табл. 4).

Табл. 4. Видовий склад газону

\begin{tabular}{|c|c|}
\hline Асортимент рослин & Стан \\
\hline Полин звичайний Artemisia vulgaris & Незадовільний \\
\hline Костриця лучна Festuca pratensis & Незадовільний \\
\hline Щириця закинута Amaranthus retroflor & Незадовільний \\
\hline Осот городній Sonchus oleraceus & Незадовільний \\
\hline Фіалка духмяна Viola odorata & Задовільний \\
\hline Зірочник середній Stellaria media & Незадовільний \\
\hline Пирій повзучий Elytrigia repens & Задовільний \\
\hline
\end{tabular}

Примітка: Вид насаджень - трав'яний покрив $12500 \mathrm{~m}^{2}$
Трав'яний покрив перебуває в незадовільному стані, і тому потребує практично повної заміни.

Обговорення результатів дослідження. Архітектурно-планувальна композиція проєктованої ділянки підлягає змінам. Усі дерева, що втратили декоративній вигляд, видаляють, запропоновано залишити тільки дерева, які $є$ у задовільному стані. До наявних дерев досаджують нові, які будуть формувати різні композиції. У кутових частинах прибудинкової території плануємо розташувати композиції, в асортимент яких будуть входити хвойні дерева та чагарники, вічнозелені, листопадні кущі, багаторічні та грунтопокривні рослини (рис. 2).

Головним декоративним елементом цих композицій має стати велике каміння, розміщене у різноманітних місцях композицій залежно від форм квітників.

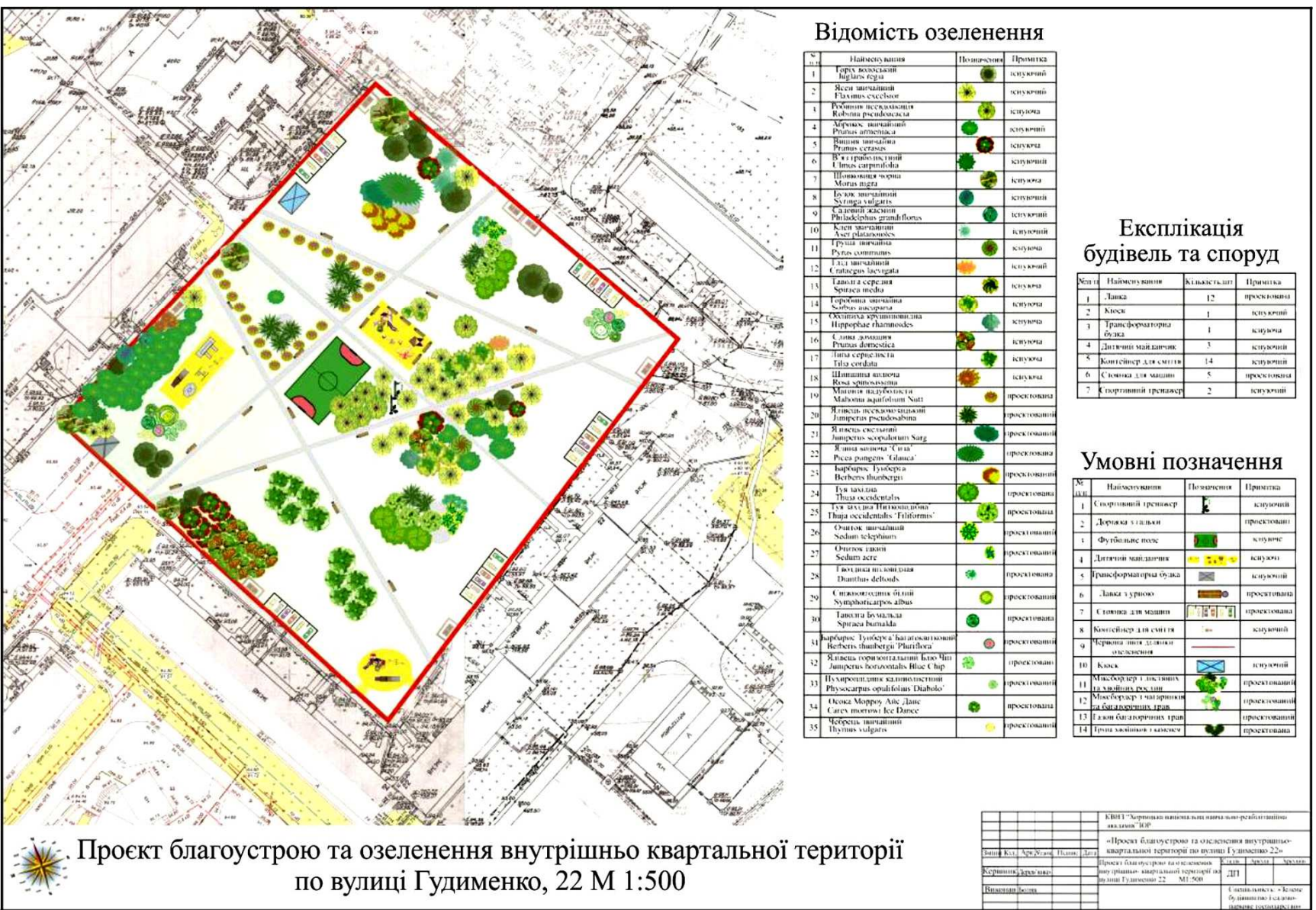

Рис. 2. План озеленення та благоустрою внутрішньо-квартальної території за адресою Гудименко, 22

Також буде запроєктовано деякі зручні рішення для мешканців навколишніх будинків, а саме обладнати стоянки для машин, які будуть відповідати вимогам пожежної безпеки та державним стандартам, буде прокладено більше доріжок. Вся територія ділянки буде обладнана лавками та урнами для сміття. Площу дитячого ігрового майданчика пропонуємо застелити спеціальним покриттям з гумової крихти.

Озеленення - важливий захід, який дає змогу надати належний естетичний та екологічний статус прибудинковій території. Шкода, але часто прибудинкова територія не оформлена, забудовники приділяють мало уваги цьому чиннику, і через це подвір'я часто невпорядковане, наповнене будівельним сміттям замість квітучих клумб і акуратно підстрижених чагарників. I постає питання: чому не озеленена прибудинкова територія?
Озеленення - це елемент благоустрою з оформлення прилеглої території зеленими насадженнями, включаючи утримання та догляд за рослинністю. Роботи з озеленення прибудинкової території багатоквартирного будинку проводяться не тільки задля краси. Вони також грають роль природної огорожі, захищають двори від бруду, пилу і шуму.

Зелене оформлення внутрішньо-квартальної прибудинкової території було спроєктовано та реалізовано ще за часів будівництва мікрорайону. Насадження, висаджені на цій території, вже досить дорослі. Деякі дерева мають деформовані стовбури і скелетні гілки, тому потрібно вжити заходів $з$ формування крони, для дерев 3 дуже великим розміром буде потрібна спеціальна техніка. Запропоновані рослини для висаджування наведено у табл. 5. 
Газон на ділянці занедбаний, дуже багато бур'янів та місць 3 пожовтілим листям, чимало стежок. Також багато ділянок, де трав'яного покриву взагалі немає. Усі рослини перебувають у недоглянутому стані. Пропонуємо висіяти суміш злакових багаторічних трав, стійких до витоптування (табл. 6). Норма висіву насіння для створення газону на дитячому майданчику становить 30 г на $1 \mathrm{~m}^{2}$.

Табл. 5. Асортимент рослин (просктований)

\begin{tabular}{|c|c|c|c|}
\hline № & Ви & Ia & \\
\hline $3 / \Pi$ & Українська назва & Латинська назва & \\
\hline 1 & Туя західна & Thuja occidentalis & 3 \\
\hline 2 & Ялина к & Picea $p$ & 1 \\
\hline 3 & $\begin{array}{l}\text { Туя західна "Ниткоподіб- } \\
\text { на" }\end{array}$ & $\begin{array}{l}\text { Thuja occidentalis "Fili- } \\
\text { forms" }\end{array}$ & 3 \\
\hline 4 & Ялівець псевдокозацький & Juniperus pseudosabina & 8 \\
\hline 5 & Яливец & pulorum Sarg & 2 \\
\hline 6 & ризонтальний & $\begin{array}{l}\text { Juniperus horizontalis "Blue } \\
\text { Chip" }\end{array}$ & 4 \\
\hline 7 & Барбари & Berberis thunbergii & 5 \\
\hline 8 & нберга "Бага- & $\begin{array}{l}\text { Berberis thunbergii "Flurif- } \\
\text { lora" }\end{array}$ & 2 \\
\hline 9 & Магоні & Mahon & 25 \\
\hline 10 & $\begin{array}{l}\text { калино- } \\
\text { lo" }\end{array}$ & pulifolius & 4 \\
\hline 11 & ик білий & arpos albus & 6 \\
\hline 12 & Тавол & Spir & 6 \\
\hline 13 & Очитол & Sedum & 5 \\
\hline 14 & Очиток їдкий & Sedum acre & 6 \\
\hline 15 & годібна & Dianthus & 75 \\
\hline 16 & Чебре & Thymus $v$ & 20 \\
\hline & & & \\
\hline
\end{tabular}

Табл. 6. Склад запропонованого газону

\begin{tabular}{|l|c|c|}
\hline \multicolumn{1}{|c|}{ Вид злаку } & Латинська назва & $\begin{array}{c}\text { Частка у су- } \\
\text { міші, \% }\end{array}$ \\
\hline Костриця лучна & Festuca pratensis & 40 \\
\hline Тимофіївка лугова & Phleum pratense & 25 \\
\hline Грястиця збірна & Dactylis glomerata & 15 \\
\hline Райграс багаторічний & Lolium perenne & 10 \\
\hline Конюшина червона & Trifolium rubens & 5 \\
\hline Конюшина біла повзуча & Trifolium repens & 5 \\
\hline
\end{tabular}

\section{Висновки}

Проєкт озеленення виконано $з$ утилітарною метою організувати відпочинок людей, які проживають у найближчих будинках. Ділянка $є$ внутрішньо-квартальною прибудинковою територією, тому розмежована на зони активного та пасивного відпочинку, що буде зручним у використанні. Додаткове формування насаджень, запропонованих у проєкті, поліпшить естетичне сприйняття території загалом та створить сприятливі умови для відпочинку та прогулянок.

Заплановано висадити декілька композицій, в асортимент яких будуть входити хвойні дерева та чагарники, вічнозелені, листопадні кущі, багаторічні та грунтопокривні рослини. Запроєктовано невеликий живопліт 3 вічнозелених багаторічних кущів, посаджених у формі незавершеного прямокутника, на території, яка оточує торгівельний МАФ.

\section{References}

1. Ananian, I. I., Bogak, L. N., \& Kuznetcov, S. G. (2010). Kompleksnaia rekonstruktciia zastroiki kak metod obespecheniia ustoichivogo razvitiia zhiloi sredy. Materialy VIII mezhdunar. nauch.-prakt. konf., (pp. 51-53). Kharkiv: KhNAGKh. [In Russian].
2. Astakhova, E. V., Krupa, T. N., \& Cherevatenko, M. T. (2009). Landshaftnyi dizain. Sovremennye resheniia. Kharkiv: Klub semeinogo dosuga, $320 \mathrm{p}$. [In Russian].

3. Award, H. (2020). Particulate matter mitigation though urban green infrastructure: research on optimization of block-scale green space. Landscape Architecture Magazine. September, 134-137.

4. Cherepanov, K. A. (2014). Problemy vybora optimalnykh parametrov zastroiki $\mathrm{v}$ zavisimosti ot sotcialnykh, ekonomicheskikh i ekologicheskikh svoistv gorodskoi sredy. Molodoi uchenyi, 2(61), 216-232. Retrieved from; https://moluch.ru/archive/61/9036/. [In Russian].

5. Didyk, V. V., \& Pavliv, A. P. (2006). Planuvannia mist. Pidruchnyk dlia stud. VNZ. Lviv: Lvivska politekhnika, 411 p. [In Ukrainian].

6. GOST 56-81-84. (2014). Polevye issledovaniia pochvy. Poriadok i sposoby provedeniia rabot, osnovnye trebovaniia $\mathrm{k}$ rezultatam. Nakaz № 130 Ministerstva ahrarnoi polityky ta prodovolstva Ukrainy vid 11 kvitnia 2014 roku "Pro prodovzhennia terminu dii haluzevykh standartiv ta pryrivnianykh do nykh inshykh normatyvnykh dokumentiv Ukrainy ta kolyshnoho SRSR". Kyiv. [In Russian].

7. Iaremenko, L. V. (2004). Planirovka i blagoustroistvo zhilykh territorii. Monografiia. Pod. obshh. red. prof. Demina N. M. Kyiv: Izdatelskii dom A. S. S., 156 p. [In Russian].

8. Khoroshkov, L. M., \& Derevianko, N. P. (2019). Proekt rekonstruktsii ta ozelenennia prylehloi terytorii oblasnoi biblioteky im. M. Horbkoho (Zaporizhzhia). Scientific Bulletin of UNFU, 29(6), 28-32. https://doi.org/10.15421/40290605

9. Kliushnychenko, Ye. Ye. (2015). Upravlinnia rozvytkom mist. Navchalnyi posibnyk. Kyiv: KNUBA, 160 p. [In Ukrainian].

10. Livinskyi, O. M., et al. (2006). Arkhitektury i budivelnykh nauk. Ukrainskyi tlumachnyi slovnyk budivelnykh terminiv; NDI ukrainoznavstva MON Ukrainy. (1st ed. add. and revised). Kyiv: Ukrainska akademiia nauk (UAN), "MP Lesia", 528 p. [In Ukrainian].

11. Mardera, A. P. (Ed.). (1995). Arkhitektura. Korotkyi slovnyk-dovidnyk. NDI teorii ta istorii arkhitektury i mistobuduvannia. Kyiv: Budivelnyk, 333 p. [In Ukrainian].

12. Milovidov, N. N., Osin, V. A., \& Shumilov, M. S. (1980). Rekonstruktciia zhiloi nastroiki. Moscow: Vysshaia shkola, $240 \mathrm{p}$. [In Russian].

13. Moroz, A. (2016). Dizain gorodskoi sredy. Landshaft i arkhitektu$r a, 2,28-30$. [In Russian].

14. Nakaz vid 24.12.2001., № 226. (2002). Pro zatverdzhennia Instruktsii z inventaryzatsii zelenykh nasadzhen u naselenykh punktakh Ukrainy. Derzhavnyi komitet budivnytstva, arkhitektury ta zhytlovoi polityky Ukrainy, Kyiv, 39 p. Retrieved from; https://zakon.rada.gov.ua/laws/show/z0182-02\#Text. [In Ukrainian].

15. Nazarenko, I. I., Polchyna, S. M., \& Nikorych, V. A. (2003). Gruntoznavstvo: pidruchnyk. Chernivtsi, 400 p. [In Ukrainian].

16. Nikolaevskaia, I. A. (1990). Blagoustroistvo gorodov. Uchebnik dlia stroit. tekhnikumov. (2nd ed. add. and revised). Moscow: Vysshaia shkola, 150 p. [In Russian].

17. Synhaivska, O. I., \& Orel, A. A. (2011). Sotsialno-planuvalni aspekty proektuvannia, rekonstruktsii ta blahoustroiu silskykh terytorii. Mistobuduvannia ta terytorialne planuvannia: nauk.tekhn. zb., 40. U 2 ch. Ch. 2, 328-339. [In Ukrainian].

18. Yurchuk, O. M. (2009). Slovnyk arkhitekturnykh terminiv. Dovidkove vydannia. Nats. un-t vodnoho hosp-va ta pryrodokorystuvannia. Rivne: NUVHP, 392 p. [In Ukrainian].

19. Zakon Ukrainy № 30. (2002). Pro Heneralnu skhemu planuvannia terytorii Ukrainy. Vidomosti Verkhovnoi Rady Ukrainy (VVR), st. 204. Retrieved from: http://zakon4.rada.gov.ua/laws/show/3059-14/print1360750552116052. [In Ukrainian].

20. Zakon Ukrainy № 10. (2007). Pro kompleksnu rekonstruktsiiu kvartaliv (mikroraioniv) zastariloho zhytlovoho fondu. Vidomosti Verkhovnoi Rady Ukrainy (VVR), 88 p. Retrieved from: http://zakon3.rada.gov.ua/laws/show/525-16. [In Ukrainian]. 
21. Zakon Ukrainy № 31. (1999). Pro arkhitekturnu diialnist. Vidomosti Verkhovnoi Rady Ukrainy (VVR), st. 246. Retrieved from: http://zakon3.rada.gov.ua/laws/show/687-14. [In Ukrainian].
22. Zakon Ukrainy № 49. (2005). Pro blahoustrii naselenykh punktiv. Vidomosti Verkhovnoi Rady Ukrainy (VVR), st. 517. Retrieved from: http://zakon.rada.gov.ua/cgi-bin/laws/main.cgi?nreg=280715. [In Ukrainian].

N. P. Derevianko

Khortytsia National Academy of Education and Rehabilitation, Zaporizhia, Ukraine

\section{PROJECT OF WELFARE PLANNING AND LANDSCAPING OF THE INTER-QUARTERLY TERRITORY IN THE CITY ZAPORIZHZYA}

Landscaping is an important measure to give the old adjacent territory an attractive aesthetic and ecological condition. In particular, the new improvement of the yard of an apartment building is important from the point of view of the convenience of the location of the necessary infrastructure facilities, which were not taken into account during the construction of the house. This may require work on the terrain and landscape and the construction of small architectural structures. The address of 22 Hudymenko Street (Heroes of the 93rd Brigade Street), Zaporizhzya needs some changes both in terms of construction work and landscaping. The plot is located in Khortytskyi district and is a rectangle. The area of the object is $13125 \mathrm{~m}^{2}$. It is surrounded on all sides by nine-storey residential buildings and is limited on all sides by a carriageway. During the day the area is well lit, but the light from the lanterns is not enough in the dark. This area is quite crowded both early in the morning and late in the evening because there is a school and a kindergarten nearby. The developed project of improvement and landscaping of this inner-quarter territory will facilitate significantly the appearance of this object. The inventory was used to establish such indicators as the balance of the territory, species composition of trees and shrubs, their number, condition and features, and also the condition of the lawn, respectively, it helped change the appearance of landscaping and make it much easier to use. It is planned to plant several compositions, the range of which will include conifers and shrubs, evergreens, deciduous shrubs, perennials and ground cover plants. A small hedge of evergreen perennial shrubs planted in the shape of an unfinished rectangle has been designed on the territory surrounding the trade of SAF.

Keywords: landscaping of the territory; city buildings; paths; benches; playground. 